\title{
Culture of Life and Culture of Death. Theological Reflection on Suicide and Euthanasia on Films
}

\section{Bruno Petrušića}

\begin{abstract}
Movies have great power to shape the system of values in contemporary culture. In this paper, we deal with theological reflection of suicide and euthanasia and their presentation as free decisions of individuals shown in the movies Seven Pounds and The Sea Inside. Also, we shall present theological reflection on culture of life and culture of death aimed to find common ground for dialogue between two opposed points of view. In the first, introductory part, we will present two views of human freedom, and we will point out that just a theological speech about freedom includes the category of responsibility. On the other hand, what happens often is neglecting categories of resposibility and absolutisation or marginalization of free will. Then we will, as an introduction to the interpretation of films, present global statistics that justify global concerns when it comes to suicide and euthanasia. Next, we will show in central part the concept of quality of life, and we will interpret it through the two mentioned films. In the last section, we conclude, despite opposition between culture of life and death, to offer category of altruism as a starting point for dialogue between the two cultures.
\end{abstract}

\section{Keywords}

Culture of death, culture of life, freedom

Every time carries its own burden. And every burden is too heavy to its time. We could say that man today is mainly burdened by his freedom. Although it seems that every generation and every time is burdened with its freedom, today it looks different. Today, one must be free, while the earlier historical epoch knows the possibility of being non-free man. Earlier one could easily be slave.

Today, freedom seems like the only absolute value in this relativistic world-pluralistic environment. Freedom is what the individual is insisting on as the only "dogma" that is unquestionable. Therefore, we are here to deal with theological evaluation of the request for application (implementation of the free will of the individual) of freedom in human life, that is at its end, its termination. Free choice of the termination (ending) of his own life today is very problematized and discussed topic that touches every corner of society, from colloquial speech up to the parliamentary debate and legislative planning solutions for problems associated with free choice of the individual's death. The framework within this paper which, at the social level, looks at freedom is neoliberal capitalism and the natural sciences. On the one hand, we have the notion of freedom as absolute

aUniversity of Split, Split, Croatia

Correspondent Author:

Bruno Petrušić, Vežarovice 10, 21215 K. Lukšić, Croatia 
because "the Market" puts in the center of economy the (absolutely?) free individual "Consumer" who establishes and regulates market relations. On the other hand, there are numerous scientists of natural and humanistic orientation, who based on past results obtained by scientific research considered that freedom of choice is an illusion (Žižek 2010: 91), which gives false comfort to humans who because of that feel dignified and superior to other living beings.

Within such a framework, thinking about freedom as a deity and denial of free choice, reflection and discourse of freedom that we are interested in this paper take place. What is important to note in these restrictions on thinking about freedom is the sense that both parties are silent about what is important in thinking about freedom. It is a "Responsibility" that is denied or at least suppressed in these two-ideological speeches about freedom. For this reason, it is no wonder that we are witnessing the silence about the moral components of society and man from those theorists of culture and society that remain within the framework that was already mentioned (Taylor 2009: 24-28). Speech on moral or immoral can be relevant only when we take account of the moral act (actus humanus), which is a material object of moral theology (Marasović 2010: 130). For reasons given earlier, it is not too much to say that "we live in an age of decadence of freedom. Freedom has been twisted (...) and often she conceals human slavery" (Berdjajev 2007: 30). She is not complete because she can be complete only in correlation with the responsibility which she necessary generates. "Freedom makes man responsible for his acts to the extent that they are willing" (Catechism of the Catholic Church no. 1734). Theology offers a much broader framework for thinking about freedom than capitalism or neuroscience does. For this reason, we consider it important to analyze the problem and the question of freedom and responsibility within theological concepts and religious world view. Because, it seems that what prevails today in consideration of freedom represents impoverishment and reductionism of our reality.

\section{THE GROWING GLOBAL CONCERN}

According to the World Health Organization (WHO), which estimated that the suicide is one of the biggest public health problems in highly developed countries, and is also on the rise in the middle and lower income countries, we can speak about growing global concern. Suicides are one of the leading underlying causes of death in the world, especially among young people. Around the world, almost a million people suffer from suicides a year (WHO speaks about approx. 800,000), which corresponds to one death by suicide every 40 seconds. Persons who commit suicide have a share of $1.4 \%$ of all deaths worldwide and suicide is the 15 th cause of death worldwide (WHO). The "black" statistics do not include suicide attempts that occur much more frequently than suicides themselves. Suicide occurs throughout the lifespan and was the second leading cause of death among 15- to 29-year-old people globally in 2012. Suicide is a global phenomenon in all regions of the world; in fact, $75 \%$ of global suicide occurred in low- and middle-income countries in 2012 (WHO).

Psychiatrist Zivko Mišević, the Head of the Department of Psychiatry in Osijek (Croatia), in an interview in which he explained the frequent reasons and motives for suicide, named firstly disturbed family relationships. In his view, he named several reasons for significant increase of suicidal rate. Families are in mess, the elderly are lonely, sick without insurance for old age, and young people are without work and prospects. In the post-war environment, they are increasing social differences. Materialistic society focused on profit developed in a culture of impatience; we want everything right now, and there is a disproportion between desires and possibilities, while neglecting spiritual values. So, Dr. Mišević directs our attention to disturbed family 
relations as one of main reasons for increasing suicide rate, and it is important to realize the influence of one larger cultural context on human being and his first "school of life", namely the family.

Euthanasia means primarily painless death or dying well. Today in the discussions, there are several forms of euthanasia, but they all mark the end of human life. What is important to note is the fact that this problem, since its inception, stepped out of the field of purely medical, and was one of the many issues that have generated invention of bioethics that is an interdisciplinary science with a steady approach and methodology. Referring to euthanasia, the author will briefly show some statistics regarding "Belgium case". Belgium legalized euthanasia in 2002. Between 2007 and 2013, the prevalence of euthanasia in Flanders, the Dutch-speaking part of Belgium, increased from $1.9 \%$ to $4.6 \%$ of all deaths. The euthanasia law in Belgium created a context of increased openness about end-of-life care and decision making in which patients could more freely discuss their wishes. Between 2007 and 2013, there were substantial increases in the proportion of euthanasia requests across various patient groups in Flanders, including groups whose requests were formerly less prevalent. These increases reflect continuing attitudinal and cultural shifts; values of autonomy and self-determination have become more prominent, and acceptance of euthanasia continues to increase in the population at large (Chambaere 2015: 1179).

\section{THE CONCEPT OF “QUALITY OF LIFE”}

In the time of the rule of positive law, it seems that "law takes priority over morals (...), as it is moral depends on the law, and not vice versa. As it is that the moral is what is legally approved, or at least not forbidden, even when it comes to matters of life and death" (Pozaić 1998: 440). And on these questions about life and death, we should not respond too easily. It is therefore important to emphasize the fact that the answers to these questions of life and death are almost always ideologically colored. The question that interests us here is the following: Is the act which is influenced by external context (disease or disorientation in the world) free? Is my act of suicide or euthanasia authentic and truly free if $\mathrm{I}$ am conditioned by my medical condition?

Answering to this question, we can show that this concept of "quality of life" is "a certain perception of each individual and his position in life in the context of their own culture and value systems in which they live in relation to their goals, expectations, models and interest" (Tomašević 2006: 403). The concept of quality of life includes physical and mental health, independence and quality of social relationships, personal context, and spirituality and personal beliefs. In such an environment where one's success and quality of life can be empirically measured and demonstrated [there are lots of organizations that are investigating objective and measurable indicators such as GDP (Gross Domestic Product) per capita and others, that can show us if one life is good-qualitative—or not...], it shows that maybe life itself becomes less important, and therefore, those lives that are considered (or that some authorities considered as such, for example the Company, Media, or Standard) to be misplaced and unfulfilled, are not worth living. And today, the biggest paradox is that, when a fundamental human right, the right to live, is prolonged throughout the world, we consider that the life is worth living only if it meets just certain conditions and almost laid standards of Western Civilization.

But what can be observed in overcoming the concept of quality of life is increasing alienation of man who ultimately will see the illusion of freedom (as determined by the standard, the disease, the media picture of normal life, or the different ways of conditioning) which is determined in various ways. In such conditions of alienation, the world has developed a wide selection of various psychosocial and (quasi) 
philosophical-theological, alternative methods and manuals of self-help and therapy, and it seems paradoxical that, "in our era of spiritual hedonism, when the goal of life is directly defined as happiness, the number of people suffering from anxiety and depression explodes" (Žižek 2010: 81).

The theological approach to this reality, the quality of life, allows us to detect those irregularities that ultimately abolish this concept. This concept seeks to create an unconscious man (a slave) and a functioning member of society based on the illusory freedom of the individual. This society needs trained consumers because it is necessary to repeatedly find spaces of expansion capital. And a variety of phrases such as "is not worth living", only prove that we are all introduced to the concept of quality of life which is governed by the basic economic terms, which only confirms the complicity of today's capitalist—liberal worldview and ideological science, which generates current condition. How does it look like when we observe human life in certain context of domination of the concept of quality of human life from theological perspective? It will be presented through interpretation of two films-Seven Pounds and The Sea Inside. Nowadays, the cultural achievements are promoting a concept that is in accordance with the requirements of the liberal-capitalist environment, which includes a unique cultural expression. This expression is now largely mediated by motion picture that transmits the values and the forms of life, while at the same time, it shapes them at its discretion. It is important to notice the unavoidable role of films (mainly Hollywood productions), which proved to be an excellent medium for communication and the designing life style and values.

\section{SUICIDE AS REDEMPTION}

The film Seven Pounds by the Italian director Gabriele Muccino speaks about the possibility of redemption in a world without God. The film takes us in the last two weeks of life of Ben Thomas (Will Smith) who eventually terminates his life via suicide in one small motel room. Ben is a successful entrepreneur and the inventor who is guilty of a traffic accident that killed seven people, including his fiancée. After this traumatic experience, Ben decides to make amends by choosing seven people who will be helped by transplantation and donating his organs to them. Immediate action of the film takes place around Ben and young woman Emily (Rosario Dawson), who needs heart transplant because of her sickness. After having rescued five people from almost certain death, Ben, having convinced that Emily and Ezra deserve his heart and eyes (cornea), kills himself by letting jellyfish in the bath which was previously filled with water and ice. Previously he also ensures that the heart and eyes will be gotten by those people he chose. The movie that talks about so deep emotions and very important issues is not so boring because Emily and Ben are becoming more emotionally and physically connected, and it seems at one point that Ben will give up his plan, but it does not happen. Emily receives his heart (only later to realize that it is his heart), and Ezra gets his eyes, so that the film ends their meeting in which they comfort each other. Although film seems rounded and it offers some answers, the final scene of the film in which Emily alone and in tears reads Ben's last letter, leaves the door open to various interpretations.

Issues that this film is opening are many and on the most of them, this film offers no answers. The question of redemption, the meaning of life, the justification of suicide and its valuation, then the issue of literalism and the limit of the concept of life, issue of love as the power of redemption, issue of victims and the systematic violence in modern societies, and the many other issues which now largely remain unanswered because when the people do not count with God, "when God is not there, it (the existence) becomes sick and the man cannot survive" (Benedict XVI 2010: 80). In such a situation, the suicide arises 
as an act of confirmation of one's own free will. What Ben does for life confirms the role of the individual as the only and the final authority which chooses those people who will be helped. The question of the meaning of life remains closed within the boundaries of the world and as such is responded only partially, in fragments. But even in these fragmented answers, love is not considered to be a meaning and the goal of human beings. Looking superficially at, for example, the relationship of Ben and Emily, and bearing in mind Christ's speech about the greatest love that exists ("who gave his life for others"), it may seem to be an act of self-sacrifice and as Ben's a true and the greatest expression of love, but it is not so. The reason is as follows. Ben does not do this out of love for Emily, but from bitterness and hatred he feels for himself. If in such cases and situations we are not careful about what lies behind the act (actus humanus) - intentions of free individuals (the subject), and if we stay within the framework of the concept of quality of life, then we have to make a positive conclusion for Ben's act. However, if we consider the opposite concept ("sanctity of life"), and if we believe that morality is determined primarily by intention, then we must condemn this act of self-sacrifice as immoral and call it a real name-suicide, because suicide is opposed to love of oneself and love of others (Catechism of the Catholic Church no. 2281).

Perhaps the systematic violence of social structure can clearly be read into the scene in which Ben saves Connie and her two children from poverty and her violent boyfriend. He comes to social worker (Holy) whom he previously donated part of his liver, and requests to give him a name, any name from the system who needs help. After she gave him Connie's contact, Ben gives them his house and some money to start a new life. In this way, he soothes his conscience ignoring the fact that there are many other names needed help in the system. It should also be noted that there is no answer to the question why he helped Connie, and not another. Arbitrariness of the individual is the ultimate foundation of reasons for the decision. There is no objective criteria. By making this a good thing, in fact, he only strengthened the power system and strengthened his logic. The right work was to change the system from within, but this film is not intended to criticize the current system of liberal capitalism, rather than promote it through a story that does not strictly specify message.

\section{THE IDEOLOGY OF MERCY-EUTHANASIA AS A DEFLECTION OF PAIN}

If the movie Seven Pounds remained undecided and open to various interpretations (none of which is not correct, or is not wrong, because it promotes a very liberal attitude), then the film The Sea Inside of Spanish director Alejandro Amenabar took openly affirmative attitude towards the right to freely end your own life. The film tells the true-life story of tetraplegic Ramon Sampedro (Javier Bardem) who fought for the right to die with dignity for 30 years. Having lost a legal battle, supported by his friends, he finally end his life by drinking cyanide. Although this film was based on true life story, insisting on some skillfully directed scenes that are strongly opting for the concept of quality of life and thus the right to die with dignity, it can be seen as one apology for modern way of thinking and the atmosphere generated by the legal and social laws and rules which ultimately give way to arbitrariness of the individual. There is one very important scene in which a Catholic priest appears, who is also a quadriplegic, who on television attacks Ramon and his family, defending human life as the highest value. And when they meet, and very vigorously (without dialing words) discuss about Ramon's request for euthanasia, Ramon is presented as the moral winner and as a skillful negotiator who successfully defended his view, and we believe that this scene would like to say to the Catholic church that She has finally lost the battle about human life that, in the modern world, is now governing by laws of the 
country which have primacy over morals or any religious doctrine.

What movie somehow propagated is not some specific morals or worldview, nor any religious doctrine, or even a positive law or rule of law as such, but, above all, it promotes respect for the free decision of the individual and self-will (of course, until this arbitrariness or leisure activity does not harm another), people alone have the right to decide their own destiny. Many authors believe that "the state should be neutral and in ideological terms that everyone should be free to live according to their own estimates of value" (Koprek 2005: 164). We believe that it is not necessary to point out that this film speaks about the issue of life within the concept of quality of life, without taking care of God as relevant hypothesis. But what is paradoxical is the fact that Ramon, despite the eagerness for death, teaches others to find their own meaning of life and values that enrich life. He considered himself to be the burden of the family and the people around him, and did not see his role as a source of comfort and hope to those who cannot live without him. He decided that he must die, and despite everything he remained in his decision. We could say that there is something deep satanic in this view (will to die).

Again, we can address the question of love that in this film appears to be insufficient to save and redeem man. Through the film, it is interesting to notice Ramon's relationship with two women-lawyer Julia (Belen Rueda) and house assistant Rosa (Lola Duenas) - who have initially disagreed to his request and desire for death. Julia is in full agreement with him (even though herself suffering from incurable diseases, does not think the same even in the moments when she ends up in a wheelchair) and entrusts him and his desire for death (which is of course only declarative), while Rosa does not accept Ramon's desire but she will eventually be one of his close friends who will help him to kill himself. Love as the inability to save his neighbor, also can be seen in relationship between Ramon and his families who care for him while he considered himself to be a burden that hampers their lives. And everything so far mentioned can help us to see how Ramon acts freely. The final scene in which Ramon died, when addressing the world (because the act is recorded), speaks about the values of this world which are the body as the only reality of man, freedom of the individual as the supreme value, and the negligence of others that are not called to do the same.

\section{THE CULTURE OF LIFE AND CULTURE OF DEATH}

The culture of life is a theological-philosophical concept, which means a commitment to respect and protect human life. Pope John Paul II mentioned this term during his trip to the United States in 1993. It is said: "The culture of life means respect for nature and protection of God's work of creation. In a special way, means respect for human life from the first moment of conception to natural death". The culture of life is taking a positive attitude towards human life, attitude that life is sacred and that it comes from God. It is the opposition to actions and behaviors which act destructively to human life such as war, abortion, euthanasia, capital punishment, contraception, artificial insemination, cloning, experimentation and killing of human embryos, mutilation, and torture. Pope John Paul II mentioned the culture of life in his encyclical Evangelium Vitae in 1995: "In our present social context, marked by a dramatic struggle between the culture of life and the culture of death, there is a need to develop a deep critical sense capable of recognizing the true values and authentic needs" (Evangelium Vitae no. 95). It is the first time that used the phrase "culture of death" which is advancing

Above all in prosperous societies, marked by an attitude of excessive preoccupation with efficiency and which sees the growing number of elderly and disabled people as intolerable and too burdensome. These people are very often 
isolated by their families and by society, which are organized almost exclusively on the basis of criteria of productive efficiency, according to which a hopelessly impaired life no longer has any value. (Evangelium Vitae no. 64)

The task of theology includes the effort that the church and the society directed towards "a new and different life practice persons, church or society" (Tanjić 2009: 17). The Magisterium of church, through several documents clearly promotes and insists on the principle of the sanctity of human life and thus raises an alternative view of the man in today's liberal world which wants freedom without responsibility. One of the key differences between the two camps (culture of life and culture of death) is in the perception of human life. To one side, a human life is something which we are condemned on and forced on, and therefore the heroic act that clearly affirms human freedom is suicide. For the other camp (culture of life), the life is gift that we have not earned, and thus we are not its final masters. When the Catechism of the Catholic Church speaks about the dignity and sanctity of human life, then it very strongly insists on human life observed as a gift which ultimately means that only "God is the Lord of life from its beginning to the end, and no one, under any circumstances, can usurp the right to direct destruction of an innocent human life" (Catechism of the Catholic Church no. 2258).

\section{SOME COMMON FEATURES}

Both presented movies want to affirm individual freedom as a fundamental feature of today's society. The movies ask us to put ourselves in a role, and to question our moral attitudes. But the intention of these films is not to promote this or that moral stance as correct, but to affirm the freedom of the individual as the only autonomous construct for the formation of a moral stance. Because of this effort, both movies are involved at some extent into ideological war being waged between the religious and secular (atheistic) spheres of society. We are witnessing, today more than ever before, to open clash around human life that is kept between the culture of life and the culture of death. Both camps have their foundation, which is within the horizon of this camp epistemologically justified, but is also exclusive, so this makes it impossible to establish a constructive dialogue. In both movies, there is a hidden thread (because it is implicitly shown in the movie), that connects everything into one harmonious ensemble, and today is seen as a generous, commendable act. It is altruism that accepts both camp as something positive and good, and as such it is a good starting point for dialogue to be open. But there is one difference that is not in the outward form of this altruistic act, but in its content. And this difference is what enables us to realize a very important difference (in almost identical cases). It is insistence on the intention (actus humanus). While the concept of quality of life (as well as the culture of death) is not accounting with the intention, because it is well that ends well, the other camp (culture of life) insists the intention that it colors the whole act as morally unacceptable and morally desirable. In both presented cases (in both movies), the intention is that the altruistic act makes morally unacceptable act.

Can we put this idea about altruism and intention as a good start for dialogue? The author sincerely hopes that dialogue is possible and that these papers will help to step in interaction with open mind to recognize the specificities of both concepts and both cultures.

\section{CONCLUSIONS}

We can conclude that today's society that denied God completely cannot but insist on the concept of quality of life in which it is life itself questionable. If this is true, can we put altrusim as a common ground for starting an open dialogue between these two cultures? 
This is an open question which has yet to be answered.

\section{References}

Benedict XVI. 2010. Svijetlo svijeta (Light of the World). Split: Verbum.

Berdjajev, N. 2007. Sudbina čovjeka u suvremenom svijetu (The Fate of Man in the Modern World). Split: Verbum.

Catechism of the Catholic Church. 1992. Retrieved (http:// www.who.int/mental_health/prevention/suicide/suicideprev ent/en/).

Chambaere, K., R. Vander Stichele, F. Mortier, J. Cohen, and L. Deliens. 2015. Recent Trends in Euthanasia and Other End-of-Life Practices in Belgium. Retrieved (www.nejm. org/doi/pdf/10.1056/NEJMc141452).

Koprek, I. 2005. "Ljudsko dostojanstvo u politici" (Human Dignity in Politics). Obnovljeni život 60(2).

Marasović, Š. 2010. Kršćanska društvena svijest (Christian Social Consciousness). Split: Crkva u svijetu.
Pozaić, V. 1998. "Eutanazija pred zakonom" (Euthanasia Under the Law). Obnovljeni život 53(4):437-446.

Tanjić, Ž. 2009. Teologija pred izazovima sadašnjeg trenutka (Theology Facing the Challenges of the Present Moment). Zagreb: Kšćanska sadašnjost.

Taylor, C. 2009. Etika autentičnosti (The Ethics of Authenticity). Split: Verbum.

Tomašević, L. 2006. "Bioetički izazovi. Izazov globalne bioetike i biotehnologije" (Bioethical Challenges. Challenge of the Global Bioethics and Biotechnologie). Bogoslovska smotra 76(2):395-415.

Žižek, S. 2010. Druga smrt neoliberalizma (First as Tragedy, Then as Farce). Zagreb: Fraktura.

\section{Bio}

Bruno Petrušić, Ph.D. student at Catholic Faculty of Theology, University of Split, Split, Croatia; research fields: dogmatical and fundamental theology, philosophy of mind and philosophy of science, cultural studies. 